\title{
The historical development of extraterritorial obligations
}

\author{
Mark Gibney
}

The year 2021 marks the ten-year anniversary of the signing of the Maastricht Principles on Extraterritorial Obligations in the Area of Economic, Social, and Cultural Rights (Maastricht ETO Principles), and this Handbook is testament to how the notion of extraterritorial human rights obligations has challenged and fundamentally changed our understanding of 'human rights'. A simple way of framing these issues is this: while international law regulates the (horizontal) relationship between sovereign states, and international human rights law regulates the (vertical) relationship between a state and its own citizens - ETOs are concerned with the 'diagonal' relationship between a state and individuals living in other countries. Or to put this in even more basic terms: what human rights obligations (if any) do states have to individuals who are outside its territorial borders (Skogly and Gibney 2002)?

One other introductory remark relates to terminology. At one point, scholars employed a variety of terms to describe what was essentially the same phenomenon: transnational; third state; transborder; international; cross-border; global; and so on. However, the most commonly used term was 'extraterritorial' and that is the term that has gained general acceptance and is used here (Gibney 2013). Still, there are several problems with this term, most notably that 'extraterritorial' might seem to refer to human rights obligations that are separate and distinct - in a word, extra - from those a state is already bound by in its domestic sphere. Because this is a misnomer, the better term would be to simply refer to a state's 'human rights obligations', with the understanding that these obligations have both an international and domestic application. Unfortunately, international law has not yet progressed to this point. Thus, 'extraterritorial' is used to describe a state's legal responsibilities to individuals living in other lands.

This introductory chapter is divided into two sections. Following this brief introduction, Part I analyzes some of the perceived shortcomings in human rights protection that have ensued from a 'territorial' reading of international human rights law. Particular focus is given to two rulings of the International Court of Justice (ICJ) - Nicaragua v. United States (1986) and Bosnia v. Serbia (2007) - both of which involve a state providing massive levels of military and economic assistance to paramilitary forces located in another country that carried out gross and systematic human rights violations (ICJ 1986) or genocide (ICJ 2007), and the question was whether the state providing such assistance had thereby acted in violation of international law. In both cases, the Court ruled that the 'assisting' state had not. The landmark ruling of the European Court of Human Rights (ECtHR) in the Bankovic case presents yet another 'territorial' reading of 
international human rights law. Finally, although these cases involve war and the violation of civil and political rights (CPR), similar issues, with similar results, have also arisen in the context of economic, social, and cultural rights (ESCR).

One of the great ironies at work here is that international human rights law has been heralded for the manner in which it has pierced the shell of state sovereignty in that states can no longer hide their egregious practices from international scrutiny on the grounds that this constituted a 'domestic' matter. However, what repeatedly happens in the extraterritorial context is that one state uses the state sovereignty of another state as a way of avoiding any responsibility for its own actions.

Part II provides a brief overview of the growing acceptance of Extraterritorial Obligations (ETO) principles. One of the central roles in all this was the establishment of the Extraterritorial Obligations (ETO) Consortium in Heidelberg, Germany in 2007, an initiative led by Rolf Kunnemann of FIAN, which is where the ETO Secretariat has been placed ever since. Later that same year, the first global ETO conference was held in Geneva and since then Consortium membership has continued to expand not only in terms of size but also in terms of global coverage.

No doubt the crowning achievement of the ETO Consortium was the adoption of the Maastricht ETO Principles by a group of eminent international lawyers in 2011. There is only space in this chapter to provide a brief overview of these principles; however, it is important to emphasize at the outset that these constitute lex lata (law as it is) and are not lex ferenda (law as it should be). In short, for the signatories of the Maastricht ETO Principles, extraterritorial human rights obligations exist under present international law.

Still, there is little question that the "territorial" approach continues to dominate the interpretation of international human rights law. For one thing, there is not a single state that has been willing to publicly acknowledge having extraterritorial human rights obligations. In addition, and making specific reference to the ICJ rulings mentioned above, there is a continued hesitancy to move away from a territorial interpretation of international law. Yet, international human rights law is changing, and given the growing recognition of the manner in which a state can have an enormous effect (both positive and negative) on human rights practices and protections in other countries, it is indeed noteworthy that ETO principles have come to be widely accepted by the U.N. treaty bodies and in other international law venues as well (Wilde 2013).

\section{Territory and human rights}

Although human rights are declared to be "universal", until fairly recently it was commonly accepted that a state's human rights obligations extended no further than its own territorial borders. There are at least two reasons for this. The first involves the international law principle that while a state can always lawfully act within its own territory, it must have permission to act in another state, otherwise it will be violating this other state's sovereignty.

The second reason comes from international human rights law itself. Although there are slight variations in terminology, human rights treaties oftentimes make reference to a state's 'territory' or to its exercise of 'jurisdiction' (or both) as a way of limiting the nature and scope of state's obligations. For example, Article 2 (1) of the International Covenant on Civil and Political Rights (ICCPR) provides: 'Each State Party to the present Covenant undertakes to respect and to ensure to all individuals within its territory and subject to its jurisdiction the rights recognized in the present Covenant...'. Article 2 (1) of the Torture Convention employs similar language: 'Each State Party shall take effective legislative, administrative, judicial or other measures to prevent acts of torture in any territory under its jurisdiction'. The final example comes from Article 1 of the European Convention on Human Rights, which references 'jurisdiction' but 
makes no mention of 'territory'. 'The High Contracting Parties shall secure to everyone within their jurisdiction the rights and freedoms defined in ... this Convention'.

What has evolved is a sharp divide between states, on the one hand, and various U.N. institutions. Seemingly without exception, states continue to act as if their human rights obligations are confined to their own domestic borders. In contrast to this, the U.N. treaty bodies and a number of Special Rapporteurs have interpreted international human rights law more broadly. For example, notwithstanding the restrictive language quoted above, both the ICCPR and the Torture Convention have been given an extraterritorial reading by the treaty bodies that monitor their implementation.

The Human Rights Committee (HRC) in its General Comment 31 (2004) on the scope of the ICCPR:

States Parties are required ... to respect and to ensure the Covenant rights to all persons who may be within their territory and to all persons subject to their jurisdiction. This means that a state party must respect and ensure the rights laid down in the Covenant to anyone within the power or effective control of that state Party, even if not situated within the territory of the state Party.

Similarly, in its ruling in Lopez v. Uruguay (HRC 1981), the HRC unanimously rejected the position put forth by Uruguay that its treaty obligations did not apply to its actions in another state (Argentina), instead holding that the key was the 'relationship between the individual and the state in relation to a violation of any of the rights set forth in the Covenant, wherever they occurred'. Employing even stronger language, in an individual opinion, Christian Tomuschat noted that Uruguay's territorial interpretation of the ICCPR would naturally lead to 'utterly absurd results'. Going even further, Tomuschat argues:

Never was it envisaged ... to grant states parties unfettered discretionary power to carry out willful and deliberate attacks against the freedom and personal integrity against their citizens abroad. Consequently, despite the wording of article 2 (1), the events which took place outside Uruguay come within the purview of the Covenant.

The Committee Against Torture (CAT) has taken a similar position, most notably in its General Comment 2:

Article 2 (1) requires that each state party shall take effective measures to prevent acts of torture not only in its sovereign territory but also 'in any territory under its jurisdiction'. The Committee has recognized that 'any territory' includes all areas where the state party exercises, directly or indirectly, in whole or in part, de jure or de facto effective control, in accordance with international law.

This same difference in interpretation also has arisen with respect to the International Covenant on Economic, Social and Cultural Rights (ICESCR) as well. Article 2 (1) of ICESCR provides:

Each state Party to the present Covenant undertakes to take steps, individually and through international assistance and co-operation, especially economic and technical, to the maximum of its available resources, with a view to achieving progressively the full realization of the rights recognized in the present Covenant by all appropriate means, including particularly the adoption of legislative measures. 
Note that neither 'territory' nor 'jurisdiction' are referenced in the treaty itself (the Optional Protocol does refer to 'jurisdiction') and the states parties are also obligated under the Convention to engage in 'international assistance and cooperation' (Skogly 2006). In addition, the Committee on Economic, Social, and Cultural Rights has repeatedly affirmed that the Convention has an extraterritorial application (Wilde 2013).

Still, states continue to resist acknowledging ETOs of any kind. One of the most revealing examples of this was the country study of Sweden conducted by the former Special Rapporteur on the Right to Health (Paul Hunt). It is well known that Sweden has long been one of the most generous countries in the world in terms of the amount of foreign assistance it provides. However, when government officials were asked whether, as a state party to the ICESCR, there was a legal obligation to provide such aid, Swedish government officials demurred. In his report, Hunt soundly rejects such a position:

If there is no legal obligation underpinning the human rights responsibility of international assistance and cooperation, inescapably all international assistance and cooperation is based fundamentally upon charity. While such a position might have been tenable 100 years ago, it is unacceptable in the twenty-first century.

(Hunt 2007, p. 28)

As a final word on this, it is by no means clear that Hunt's scathing criticism brought about any change in state policy or practices - either in Sweden or in any other country. Instead, 'territory' has become the default position even for a treaty where there is no mention of this.

\section{Security issues}

When human rights scholars began to question the primacy of "territory", it was generally on the basis of the kinds of inconsistent results this so often led to. As an example, one of the most widely recognized principles in international law is nonrefoulement: a state has an obligation not to send an individual (usually a foreign national who has arrived at its borders seeking refugee protection) back to a country where this person's life or freedom would be threatened. Yet, while there is strong adherence to this principle (at least in theory), at the same time international law seems to allow states to pursue policies that can have devastating consequences for those living in other states. One such example has been the ability to sell massive amounts of military equipment to countries that then use these weapons against civilian populations.

The ostensible difference between these two scenarios is that, in the first case, the foreign national is at some point on this other state's territory. This, among other things, helps explain how and why states are now making such efforts to prevent refugees from being able to reach their national borders in the first place (Gammeltoft-Hansen; Gombeer and Smis, this volume). In the scenario involving arms sales, no territorial link is present. Based on this distinction, in the first case the state has a legal obligation to provide human rights protection, while in the second case, at least under a territorial interpretation of international human rights law, the sending state has no obligations outside its borders. One question is whether the Arms Trade Treaty (ATT), which went into effect in December 2014, will significantly change this (Aksenova, this volume). The same issue arises with respect to the Responsibility to Protect (R2P) initiative, which places a duty on the international community to intervene in countries experiencing gross and systematic human rights violations (Gibney 2011). Still, the 'territorial' interpretation of international human rights law remains dominant.

This is not to suggest that states are able to act outside their own national borders with impunity. The clearest cases arise when a state acts directly in another state, as was the case in the 
ICJ's rulings in the Namibia Advisory Opinion (ICJ 1970), the Wall Advisory Opinion (ICJ 2004), and DRC v. Uganda (ICJ 2005) (Wilde 2013). The Court took a similar position in Nicaragua v. United States (ICJ 1986) when it ruled that the United States had acted in violation of international law when U.S. agents acted directly against the ruling government in that country, including mining Nicaragua's harbors.

However, the more vexing question is when a state does not act directly but through local proxies instead. This was the second question of state responsibility raised in the Nicaragua case and the ICJ ruled that the United States was not responsible for any of the widespread atrocities carried out by the Contra rebel forces, notwithstanding the substantial levels of military, political, and economic support provided by the United States. According to the Court, in order for such responsibility to arise it would have to be established that the U.S. government had exercised 'effective control' over the Contras. It remains unclear when this standard is met; however, at one point the Court framed the issue in these terms:

In light of the evidence and material available to it, the Court is not satisfied that all the operations launched by the contra force, at every stage of the conflict, reflected strategy and tactics wholly devised by the United States.

(ICJ 1986, para. 106 (emphases supplied))

There are a number of questions raised by this case (Gibney, Tomasevski, and Vedsted-Hansen 1999). One simply is the strong disincentive that states will have of exercising 'effective control' over another state or an entity in another state, thereby opening itself up to a finding of state responsibility for any resulting harms carried out by the recipient. A second problem is the near impossibility of ever meeting the 'effective control' standard in the first place. The Contras were essentially creatures of the U.S. government and the relationship between the two was extraordinarily close, something the ICJ itself readily acknowledged. Still, the Court ruled that in order for the United States to be responsible for the human rights violations carried out by the Contras, the U.S. would have to control virtually every activity these paramilitary forces engaged in. Finally, under the Court's approach, state responsibility is treated as being either-or: either a state has exercised 'effective control' over the foreign entity and is therefore fully responsible for its human rights violations - or, much more likely, it has not exercised that level of control (purposely or otherwise), in which case it will not bear any responsible at all.

What is missing in such an approach is any sense of the nature and level of support that is provided, as well as the foreseeability or likelihood of harm occurring because of this assistance. Reflecting many of these concerns, the International Criminal Tribunal for the (Former) Yugoslavia (ICTY) described the ICJ's 'effective control' standard as not being consonant with the 'very logic of the entire system of state responsibility', and also 'at variance with judicial and state practice'. Rather than employing this standard, the ICTY relied on an 'overall control' standard instead.

In order to attribute the acts of the military or paramilitary group to a state, it must be proved that the state wields overall control over the group, not only by equipping and financing the group, but also by coordinating or helping in the general planning of its military activity. Only then can the state be held internationally accountable for any misconduct of the group. However, it is not necessary that, in addition, the state should also issue, either to the head or to members of the group, instructions for the commission of specific acts contrary to international law.

(ICTY 1999, para. 131) 
More than two decades after its decision in Nicaragua, the ICJ returned to the issue of extraterritorial state responsibility in Bosnia v. Serbia (ICJ 2007). Similar to Nicaragua, the key issue in this case was whether Serbia was responsible for genocide that had been carried out by various Bosnian Serb paramilitary forces it was allied with. By the time this case arose, the U.N. International Law Commission had completed its (Draft) Articles on State Responsibility (ASR) (Crawford 2002) and the ICJ relied heavily on these. The first issue it addressed was whether the Bosnian Serb forces were acting as 'state agents' for the Serbian state. Interpreting Article 4 ASR, the Court held that there was no evidence they were de jure state agents, and in order to be considered as de facto state agents of Serbia it would have to be established that these paramilitary forces had 'complete dependence' on the Serb government, which it concluded had not been established.

The second issue was whether, under Article 8 ASR, the Serbian government had 'directed and controlled' the actions of the Bosnian Serb forces at the time genocide was carried out. Taking direct aim at the ICTY's ruling in Tadic, the Court invoked the 'effective control' test from its Nicaragua decision, holding that in order to achieve this standard it must be shown 'that this "effective control" was exercised, or that the state's instructions were given, in respect of each operation in which the alleged violations occurred, not generally in respect of the overall operations taken by the persons or groups of persons having committed the violations' (ICJ 2007, para. 400). Making reference to what it perceived as 'differences' between the Bosnian Serbs and the Serbian government following the overthrow of Srebrenica when most acts of genocide had taken place, the Court ruled that this requisite level of 'effective control' had not been achieved.

The final issue was whether Serbia was responsible for being complicit in genocide and the ICJ applied Article 16 of the Articles on State Responsibility, which reads:

A state which aids or assists another state in the commission of an internationally wrongful act by the latter is internationally responsible for doing so if:

- (a) That state does so with knowledge of the circumstances of the internationally wrongful act; and

- (b) The act would be internationally wrongful if committed by that state.

The Court rejected the claim that Serbia was 'complicit' in genocide on the grounds that it had not been proven 'beyond any doubt' that Serbia possessed the specific intent (dolus specialis) required by the Genocide Convention.

A point which is clearly decisive in this connection is that it was not conclusively shown that the decision to eliminate physically the adult male population of the Muslim community from Srebrenica was brought to the attention of the Belgrade authorities when it was taken; the ... decision was taken shortly before it was actually carried out, a process that took a very short time (essentially between 13 and 16 July 1995), despite the exceptionally high number of victims. It has therefore not been conclusively established that, at the crucial time, the FRY supplied aid to the perpetrators of the genocide in full awareness that the aid supplied would be used to commit genocide.

(ICJ 2007, para. 423)

In sum, notwithstanding the widespread atrocities suffered by the Bosnian Muslim population and despite the extraordinarily close ties between the Bosnian Serb forces and the Serbian government, the ICJ ruled that the Serbian Republic was not 'responsible' in any manner for the acts of genocide that occurred following the fall of Srebrenica (Gibney 2007). However, in a part 
of the Bosnia ruling that has received only minor attention, the Court held that Serbia had failed to meet its obligations to 'prevent' genocide and to 'punish' those who had engaged in it. The former was based on the apparent ability of the Serb state to 'influence' the actions of its Bosnian Serb allies, and the latter on the basis that Serbia had failed to fully cooperate with the ICTY.

To be clear, in neither of these two cases did the ICJ announce that it was basing its decision on a 'territorial' interpretation of international law. Yet, one way of understanding that this is exactly what the Court has done is to look at a situation where a government provides similar forms of assistance - but to a domestic group rather than to an entity in some other country. One such example would be the relationship between the government of Sudan and the Janjaweed, a domestic paramilitary group that has engaged in all manner of human rights atrocities, including ethnic cleansing. The Sudanese government has worked closely with the Janjaweed forces, but certainly no closer than the United States with the Contras or the Serbian government with various Bosnian Serb allies. And yet, Sudan's responsibility goes unquestioned. The only difference is that in Nicaragua and Bosnia territorial borders were crossed, while this is not the case in the Sudan.

Before turning to situations involving ESCR, the last security case to be mentioned is the ECtHR's landmark ruling in Bankovic v. Belgium et al. (ECtHR 2001), which was based on a North Atlantic Treaty Organization (NATO) bombing mission over Serbia (before it was a state party to the European Convention) that harmed and/or killed a group of civilians, who then brought suit against the NATO members. The key issue was whether these individuals were within the 'jurisdiction' of these states at the time these events occurred. As noted earlier, Article 1 of the European Convention reads: 'The High Contracting Parties shall secure to everyone within their jurisdiction the rights and freedoms defined in ... this Convention'. In a Grand Chamber decision, the ECtHR ruled these individuals were not within the jurisdiction of any of the state parties and dismissed the case as inadmissible (Lawson 2004; Orakhelashvili 2003).

In arriving at its conclusion, the ECtHR noted that the original version of Article 1 had included the term 'territory', and although this was removed in the final draft, the ECtHR maintained that the Convention remained territorial - or what it described as being 'essentially' or 'primarily' territorial - and that because of this the Convention only applied extraterritorially under 'exceptional circumstances'. It remains unclear when an 'exceptional circumstance' exists. However, what we do know from the result in this case is that killing or harming civilians in foreign lands by means of an aerial bombardment (somehow) does not meet this standard.

Since Bankovic, the ECtHR has backtracked, at least to some degree, from its ruling (Milanovic 2012). Still, with extraordinarily rare exception, when the state parties act outside of Europe - as they do almost as a matter of course - they will not be regulated by the strictures of the European Convention. Instead, there is one set of human rights standards within Europe - and another set of standards when these states operate outside of 'Europe' (Roxstrom, Gibney, and Einarsen 2005).

\section{Non-security issues}

As we have seen in the analysis above, issues of extraterritorial human rights obligations might arise at times in the conduct of security operations. However, the more common situation occurs far from the field of battle. Yet, even here there has been a strong tendency to read international human rights law in a territorial fashion, as we will see in the following two case studies.

The first was developed by the Crowley Program in International Human Rights at Fordham University Law School (Hoodbhoy, Flaherty, and Higgins 2005), and it centres around what has been termed the Mexico City Policy ('Global Gag Order') and the human rights 
consequences this U.S. law has had on healthcare practices in Kenya (and, presumably, other developing countries as well). By way of background, the Mexico City Policy was an Executive Memorandum issued by President George W. Bush on 22 January 2001 that reinstated a set of restrictions prohibiting foreign non-governmental recipients of U.S. family planning funds from promoting or advocating abortion as a means of family planning in situations other than that of protecting a woman's health. These restrictions bind U.S. Agency for International Development (USAID), the principal conduit through which U.S. funding for healthcare is provided to Kenya and other developing countries. At the time the Global Gag Rule was issued in 2001, USAID provided 16 percent of all healthcare funding to Kenya and 28.4 percent of the Ministry of Health's development budget. What also has to be noted is that although the United States has signed the ICESCR, it has never ratified the treaty. Still, as a signatory it has obligated itself not to violate the Convention's provisions. And as mentioned earlier, the ICESCR makes no mention of either 'territory' or 'jurisdiction'.

The Fordham study focused on two Kenyan family planning organizations that refused to sign the required pledge not 'to perform or actively promote abortion', and USAID responded by cutting off funding to both, which ultimately resulted in the closure of a number of family planning clinics and outreach programs. The end result of all this is that the number of Kenyan women receiving family planning services was severely reduced, leading to a serious deterioration of maternal health in that country. In sum, there is a direct link between the reduction of U.S. aid and ESCR violations in Kenya. The (legal) question is whether the U.S. has thereby committed an internationally wrongful act. Another way of framing this is to ask whether the U.S. has any human rights obligations to women in Kenya and whether it has violated these obligations by eliminating family planning funds as it did.

The second case involves the Canadian mining corporation TVI Pacific and its operations on the island of Mindanao in the Philippines (Seck 2008). In 2004, a delegation of community members from Mindanao traveled to Canada and met with Canadian lawmakers about the environmental devastation and health consequences brought about by TVI Pacific's operations. In March 2005, two community members presented additional evidence to a parliamentary committee, which then endorsed a proposal to establish 'clear legal norms' to regulate Canadian multinational corporations (MNCs) in their operations in countries outside of Canada. However, such legislation was not pursued any further at that time because of governmental concerns that the international community is still in the early stages of defining and measuring corporate social responsibility, especially in the area of human rights.

Not to be overlooked, the government of the Philippines has failed to protect its own citizens and has therefore committed a human rights violation itself. However, what about Canada and other countries whose MNCs are operating in the world, oftentimes with limited regulation? Although there have been some recent domestic efforts to regulate MNCs, international law continues to struggle with this issue, and one important reason is the great hesitancy in recognizing that states have human rights obligations beyond their own territorial borders.

\section{The extraterritorial challenge}

As we have seen in the previous section, although a 'territorial' interpretation of international human rights law continues to dominate, it is important to note that seldom is a strictly territorial approach taken. For example, in the Nicaragua case, the ICJ not only ruled against the United States for harmful acts carried out directly by U.S. agents in Nicaragua, but it also ruled that the U.S. would bear responsibility for human rights violations carried out by the Contras - so long 
as it exercised 'effective control' over them. Similarly, in the Bankovic case, the ECtHR did not adopt a strictly 'territorial' approach. Rather, it held that the European Convention could apply outside of 'Europe' - but only under 'exceptional circumstances'.

Aside from the problem of knowing when these standards happen to be reached (let alone where they came from) what both of these adjudicatory bodies appear to be doing is hedging their bets: international human rights treaties are territorial (for the most part). This is easier to see in Bankovic. The ECtHR noted that the original draft of the Convention included a reference to 'territory' in Article 1, and although this term was removed in the final draft, the ECtHR maintained the position that the territorial basis of the Convention had not been changed. On the other hand, and for whatever reasons, the ECtHR found it necessary to allow for certain exceptions and in that way interpreted the treaty as being 'primarily' or 'essentially' territorial. The problem is that a treaty cannot be both territorial and non-territorial or semi-territorial at the same time.

Around the turn of the century, scholars and members of civil society organizations began reacting to the inconsistencies in these rulings and the manner in which human rights were left unprotected under a territorial approach. In addition, what also became evident is that many states that adhered to human rights standards at home tended to ignore these same standards when they operated in the world.

In the Spring 2003, sympathetic members of the U.N. Committee on Economic, Social, and Cultural Rights met with some human rights practitioners and scholars to discuss ETOs and what recognition of such obligations would mean in the area of ESCR. In 2007, a group of five convened in Heidelberg, Germany and established the Extraterritorial Obligations (ETO) Consortium. Later that same year, the first global ETO conference was held in Geneva.

In 2011, 40 prominent international lawyers signed the Maastricht ETO Principles in the Area of Economic, Social, and Cultural Rights (de Schutter et al. 2012). The Maastricht ETO Principles are a clear articulation that, under present international law, all states have ETOs. As General Principle 3 reads: 'States have obligations to respect, protect and fulfil human rights, including civil, cultural, economic, political and social rights, both within their territories and extra-territorially'. Furthermore, Article 9 entitled Scope of Jurisdiction provides:

A state has obligations to respect, protect and fulfil economic, social and cultural rights in any of the following:

a) situations over which it exercises authority or effective control, whether or not such control is exercised in accordance with international law;

b) situations over which state acts or omissions bring about foreseeable effects on the enjoyment of economic, social and cultural rights, whether within or outside its territory;

c) situations in which the state, acting separately or jointly, whether through its executive, legislative or judicial branches, is in a position to exercise decisive influence or to take measures to realize economic, social and cultural rights extraterritorially, in accordance with international law.

One way to get a sense of the nature and scope of the Maastricht ETO Principles is to contrast its reading of international law regarding the regulation of MNCs with the Guiding Principles on Business and Human Rights: Implementing the United Nations 'Protect, Respect and Remedy' Framework (U.N. High Commissioner for Human Rights 2011). Principle 2 of the Guiding Principles reads: 'States should set out clearly the expectation that all business enterprises domiciled in their 
territory and/or jurisdiction respect human rights throughout their operations'. However, as the commentary makes clear, such regulation of business operations in other states is permissive but not required.

States are not generally required under international human rights law to regulate the extraterritorial activities domiciled in their territory and/or jurisdiction. Nor are they generally prohibited from doing so, provided there is a recognized jurisdictional basis. Within these parameters some human rights treaty bodies recommend that home states take steps to prevent abuse abroad by business enterprises within their jurisdiction.

In contrast to this, under the Maastricht ETO Principles not only does the 'home' state have an obligation to regulate its own MNCs, but so do other states that are in a position to do so. Principle 24 Obligation to Regulate reads:

All states must take necessary measures to ensure that non-state actors which they are in a position to regulate ... such as private individuals and organizations, and transnational corporations and other business enterprises, do not nullify or impair the enjoyment of economic, social and cultural rights. These include administrative, legislative, investigative, adjudicatory and other measures. All other states have a duty to refrain from nullifying or impairing the discharge of this obligation to protect.

ETO Principles are now frequently referenced by the U.N. treaty bodies in General Comments and Concluding Observations to state reports. In addition, a number of U.N. Special Rapporteurs have explicitly acknowledged states' ETOs (ESCR-Net 2015).

Beyond this, in June 2014, the Human Rights Council adopted a resolution backed by Ecuador and South Africa to establish an Inter-Government Working Group with the mandate to elaborate a legally binding instrument on Transnational Corporations and Other Business Enterprises with Respect to Human Rights. A second revised draft of a treaty was completed in August 2020. It is important to note that the draft treaty would still place regulatory responsibility only on states parties. A proposal that would go much further than this in protecting human rights would be to explicitly recognize that MNCs have human rights obligations (Erdem Turkelli 2020).

\section{Conclusion}

Although human rights are declared to be universal, the responsibility to protect such rights has long been confined by territorial considerations. In that way, while a state has human rights obligations to its own citizens, what remains contested is whether it has any obligations to those living in other countries. One reason for this is the international law principle that a state is not to infringe on the sovereignty of another state. A second reason is that many international human rights treaties contain language that reifies territorial limitations. Yet, even treaties that make no reference to 'territory' have quite often been given a territorial interpretation, particularly by states themselves.

Two decades ago, scholars first began to challenge the primacy of territory, mainly on the basis that this often led to situations where human rights were left unprotected. Moreover, there was also a certain degree of irony in that so many states that adhered to human rights principles at home were so willing to abandon, or at least turn a blind eye toward, these very same principles when they acted outside their national borders. 
The word 'development' in the title of this chapter is a bit misleading because the notion of ETOs has not progressed in any kind of linear or systematic fashion. For one thing, states (or at least developed states) have been quite resistant to this idea, although there are at least some indications of cracks in the sovereignty wall. On the other hand, most segments of the United Nations support an extraterritorial interpretation of international human rights law. However, two of the major impediments are U.N. agencies: the International Law Commission and the International Court of Justice.

The European Court of Human Rights has also taken a puzzling route on this matter. Prior to its landmark ruling in Bankovic, the ECtHR readily recognized the extraterritorial application of the European Convention (Roxstrom, Gibney, and Einarsen 2005). Bankovic changed this dramatically, although the ECtHR also provided some leeway for the geographic expansion of Convention protection. Still, as shown by the active involvement of so many European governments in various aspects of the extraordinary rendition program (see Guild, this volume), assigning state responsibility for human rights harms that occur outside of 'Europe' will be difficult at best.

Almost as a matter of course, states have used 'territory' as a way of avoiding their own human rights obligations. To reaffirm the principle set forth at the outset of this chapter: all states have human rights obligations and these obligations apply both at home and abroad.

\section{References}

Arms Trade Treaty (ATT) (2013) Adopted and opened for signature, ratification and signature by General Assembly resolution 67/234B 2 April 2013, Entry into force 24 December 2014.

Committee Against Torture (CAT) (2008) GC 2 on the implementation of article 2 by states parties, U.N. Doc CAT/C/GC/2.

Convention against Torture and Other Cruel, Inhuman or Degrading Treatment or Punishment (1984) Adopted and opened for signature, ratification and accession by General Assembly resolution 39/46 of 10 December 1984, Entry into force 26 June 1987.

Crawford, J. (2002) The International Law Commission's Articles on State Responsibility: Introduction, Text and Commentaries, Cambridge University Press.

De Schutter, O. et al. (2012) 'Commentary to the Maastricht Principles on Extraterritorial Obligations of States in the Area of Economic, Social and Cultural Rights', Human Rights Quarterly 34, 1084-1169.

Erdem Turkelli, G. (2020) Children's Rights and Business: Governing Obligations and Responsibilities, Cambridge University Press.

ESCR-Net. (2015) 'Human Rights Law Sources: UN Pronouncements on Extra-Territorial Obligations', https://www.escr-net.org/resources/human-rights-law-sources-un-pronouncements-extra-territorial-obligations [accessed DATE].

European Convention for the Protection of Human Rights and Fundamental Freedoms (1950) Nov. 4, 1950, 213 U.N.T.S. 222.

European Court of Human Rights (ECtHR) (2001) Bankovic et al. v. Belgium et al., Application no: $52207 / 99$.

Gibney, M. (2007) ‘Genocide and State Responsibility', Human Rights Law Review 7, 760-773.

- (2011) 'Universal Duties: The Responsibility to Protect, the Duty to Prevent (Genocide), and Extraterritorial Human Rights Obligations', Global Responsibility to Protect 3, 123-151.

- (2013) 'On Terminology: Extraterritorial Obligations' in Langford, M., Vandenhole, W., Scheinin, M. and van Genugten,W. (eds). Global Justice, State Duties: The Extraterritorial Scope of Economic, Social, and Cultural Rights in International Law, Cambridge University Press.

Gibney, M., Tomasevski, K. and Vedsted-Hansen, J. (1999) Transnational State Responsibility for Violations of Human Rights, Harvard Human Rights Journal 12, 267-296. 
Human Rights Committee (HRC) (1981) Sergio Euben Lopez Burgos v. Uruguay, Communication No. R.12/52, U.N. Doc. Supp. No. 40 (A/36/40).

(2004) GC 31 on the nature of the general legal obligation imposed on states parties to the Covenant, CCPR/C/21/Rev.1/Add. 1326.

International Court of Justice (ICJ) (1970) Legal Consequences for States of the Continued Presence of South Africa in Namibia (South West Africa) Notwithstanding Security Council Resolution, Advisory Opinion.

(1986) Case Concerning Military and Paramilitary Activities in and against Nicaragua (Nicaragua v. United States).

(2004) Legal Consequences of the Construction of a Wall in the Occupied Palestinian Territories, Advisory Opinion.

(2005) Case Concerning Armed Activities on the Territory of the Congo (Democratic Republic of the Congo v. Uganda), Judgment.

(2007) Application of the Convention on the Prevention and Punishment of the Crime of Genocide (Bosnia and Herzegovina v. Serbia and Montenegro), Judgment.

International Covenant on Civil and Political Rights (ICCPR) (1966) Adopted and opened for signature, ratification and accession by General Assembly resolution 2200A (XXI) of 16 December 1966, entry into force 23 March 1976.

International Covenant on Economic, Social and Cultural Rights (ICESCR) (1966) Adopted and opened for signature, ratification and accession by General Assembly resolution 2200A (XXI) of 16 December 1966, entry into force 3 January 1976.

International Criminal Tribunal for the (Former) Yugoslavia (ICTY) (1999) Prosecutor v. Tadic, Case No. IT-94-1-A, Judgment.

Hoodbhoy, M., Flaherty, M.S. and Higgins, T.E. (2005) 'Exporting Despair: The Human Rights Implications of U.S. Restrictions on Foreign Health Care Funding in Kenya', Fordham International Law Journal $29,1-118$.

Hunt, P. (2007) Report of the Special Rapporteur on the Right of Everyone to the Enjoyment of the Highest Attainable Standard of Physical and Mental Health, Addendum, Mission to Sweden. U.N. Human Rights Council, Al/1HRC/4/28/Add.2.

Lawson, R. (2004) 'Life After Bankovic: On the Extraterritorial Application of the European Convention on Human Rights' in Coomens, F. and Kamminga, M.T. (eds). Extraterritorial Application of Human Rights Treaties, Intersentia.

Milanovic, M. (2012) 'Al-Skeini and Al-Jedda in Strasbourg', The European Journal of International Law 23, $121-139$.

Office of the High Commissioner for Human Rights (2011) Guiding Principles for Business and Human Rights.

Optional Protocol to the International Covenant on Economic, Social and Cultural Rights (2008) 10 December 2008.

Orakhelashvili,A. (2003) 'Restrictive Interpretation of Human Rights Treaties in the Recent Jurisprudence of the European Court of Human Rights', European Journal of International Law 14, 529-568.

Roxstrom, E., Gibney, M. and Einarsen, T. (2005) 'The NATO Bombing Case and the Limits of Western Human Rights Protection', Boston University International Law Journal 23, 55-136.

Seck, S. (2008) 'Home State Responsibility and Local Communities: The Case of Global Mining', Yale Human Rights and Development Law Journal 11, 177-206.

Skogly, S. (2006) Beyond National Borders: States' Human Rights Obligations in International Cooperation, Intersentia.

Skogly, S. and Gibney, M. (2002) 'Transnational Human Rights Obligations', Human Rights Quarterly 24, 781-798.

Wilde, R. (2013) 'Human Rights Beyond Borders at the World Court: The Significance of the International Court of Justice's Jurisprudence on the Extraterritorial Application of International Human Rights Law Treaties', Chinese Journal of International Law 12, 639-677. 